\title{
EL GERMEN DEL DERECHO CONSTITUCIONAL COMO DISCIPLINA JURÍDICA EN EL CONSTITUCIONALISMO DECIMONÓNICO ESPAÑOL
}

\author{
REMEDIO SÁNCHEZ FERRIZ
}


I. IDEAS Y FUNDAMENTOS CONSTITUCIONALES; CONDICIONANTES DE LA REALIDAD POLÍTICA EN LA ESPAÑA DEL XIX. 1. El primer constitucionalismo español. 2. Periodo intermedio de aparente estancamiento; 3. El liberalismo doctrinario de la Constitución española de 1845 y el fracaso del Bienio Progresista. 4. Ultimo tercio del siglo. Especial significación del periodo de la Restauración. 4.1 Junto a técnicas jurídicas, alumbran las de naturaleza democrática. 4.2. Dimension social del Estado constitucional. II. EL DERECHO POLÍTICO-CONSTITUCIONAL EN LAS PRIMERAS MANIFESTACIONES DE LA MANUALÍSTICA: 1. Catecismos para dar a conocer la Constitución. 2. Su evolución en el reinado de Isabel II. 3. La consolidación del Derecho Político Constitucional en la Restauración. III. MADURACIÓN DE LAS IDEAS PRECEDENTES EN TORNO A LOS DERECHOS DE PARTICIPACIÓN Y/O LIBERTADES PÚBLICAS. 


\title{
EL GERMEN DEL DERECHO CONSTITUCIONAL COMO DISCIPLINA JURÍDICA EN EL CONSTITUCIONALISMO DECIMONÓNICO ESPAÑOL ${ }^{1}$
}

POR

\section{REMEDIO SÁNCHEZ FERRIZ}

\author{
Universitat de València
}

En puridad, no cabe hablar de Derecho constitucional como ciencia jurídica hasta bien entrado el siglo XIX (y, aun entonces, sin una clara distinción entre el Derecho Público y el propiamente Constitucional) aunque sus contenidos

${ }^{1}$ El presente trabajo es fruto de una meditada reflexión sobre el que yo misma publiqué hace unos 10 años cuando, en los últimos estertores de la L.R.U. decenas de jóvenes profesores se encontraron con la oportunidad de consolidar sus plazas y, por lo que de algunos de ellos sé, les resultó entonces de utilidad en la preparación de sus respectivas memorias. La reciente Jornada que Lorenzo Cotino y Miguel Ángel Presno Linera organizaron en el Centro de Estudios Constitucionales, como II Congreso de Innovación educativa en Derecho constitucional (todo ello en el marco de los Proyectos de innovación educativa que ambos desarrollan y por mi parte, en concreto, por el que Lorenzo Cotino dirige proyecto MICINN (2010-2012), «Las libertades informativas en el contexto de la web 2.0 y las redes sociales: redefinición, garantías y límites» (DER2009-14519-C05-01, subprograma JURI) me trajo a la mente una serie de reflexiones sobre lo que queda del enfoque y contenidos con que mi generación preparó la disciplina. El interesante debate allí suscitado sobre la incidencia de las nuevas tecnologías y técnicas de aprendizaje, en concreto para nuestra disciplina, me hizo reflexionar de nuevo sobre si los viejos métodos tienen algo que seguir aportando o no a las nuevas generaciones de cuyos medios tecnológicos actuales carecíamos hace solo una década. 
y su objeto han venido constituyendo el eje de las preocupaciones y reflexiones de todo pensador a lo largo de la historia. El hecho de que su configuración definitiva se sitúe en torno al fenómeno del constitucionalismo moderno no es óbice para que se valoren en su justa medida las aportaciones precedentes que se remontan hasta el pensamiento clásico².

Es la extraordinaria imbricación de las teorías políticas con las circunstancias en que las mismas se van generando la que permite explicar las dificultades que tales teorías han hallado para asentarse (requisito previo a toda pretensión de establecer una ciencia) a lo largo de las muy diversas experiencias históricas. De ahí, el peso que las circunstancias políticas han tenido siempre en el desarrollo de las ideas. De ahí, por el contrario, el peso que también han tenido las ideas en la aparición de nuevas formas políticas de suerte que una adecuada comprensión de los fenómenos político-constitucionales exige tener presente una doble y paralela evolución, la de las ideas y la de las circunstancias políticas en que surgen ${ }^{3}$.

Lo intenté presentando una Ponencia en la que me preguntaba qué papel tiene hoy la Manualística en un mundo docente dominado por las nuevas tecnologías con las que resulta fácil consultar, entre otros tantísimos datos, el complejísimo sistema de fuentes de nuestro Estado autonómico y en el que se están llegando a replantear todo tipo de metodologías en el estudio. Mi inquietud se reconduce en dicha ponencia, breve, a plantear si la introducción de tan novedosas tecnologías no afectará a los contenidos básicos del Derecho Constitucional o si, por el contrario, éstos deben considerarse referencias inexcusables hasta el punto de poder (y deber) primar sobre los métodos cuando de su convivencia se dedujera incompatibilidad.

2 Por todos, HÉlLER, H. (1933) Concepto, desarrollo y función de la Ciencia Política (trad. de N. Pérez Serrano). Madrid, p. 10: «Como se ve, en la antigua Grecia hallamos ya una Ciencia Política que, por lo que respecta al objeto y métodos, ofrece una abigarrada variedad... tropezamos con una técnica del Poder político, con un tratado de ciudadanía, con una filosofía moral, con una Metafísica histórica, con una Sociología o con una disciplina especial... De las modernas posiciones, sólo una fue ignorada totalmente por los griegos: la doctrina jurídico-dogmática del Estado; por que si bien Aristóteles realizó notables investigaciones de Derecho comparado y de carácter histórico-jurídico, no conocieron los griegos una teoría general del Estado, como tampoco la conocieron propiamente los romanos, ya que constituye en realidad una aportación de la Baja Edad Media».

3 Sin olvidar que en nuestro caso la presencia del Monarca en un potencia extranjera y las pretensiones de ésta planteaban también cuestiones de orden internacional como se pone de relieve en el estudio de SEVILLA MERINO J.,(1977) Las ideas internacionales en las Cortes de Cádiz. Valencia, Cátedra Fedrique Furió Ceriol, n. ${ }^{\circ} 3$. 


\section{IDEAS CONSTITUCIONALES COMO GERMEN DE UNA DISCIPLINA ABSOLUTAMENTE CONDICIONADA POR LA REALIDAD POLÍTICA. LA ESPAÑA DEL SIGLO XIX}

Aunque la afirmación de este epígrafe es de tan general aplicación que pudiera ser considerada una obviedad, cobra extraordinario interés para el caso del inicio de nuestro constitucionalismo, marcado, como lo estuvo, por una peculiar situación derivada de la ocupación francesa:

«Así principiaba en nuestro país la revolución política. No era obra de las ideas y de la convicción; era obra de la necesidad. Compuesto únicamente el Estado del trono y del pueblo4, quedó sólo el pueblo cuando hubo desaparecido el trono. Los Ayuntamientos eran la única institución independiente y política que nos había quedado: a manera, pues, de grandes Ayuntamientos crearonse esos centros provinciales, para organizar y dirigir la acción de todos contra el enemigo común... La España, volvemos a repetirlo, fue sin saberlo una confederación de repúblicas que peleaban por su Rey. La democracia pura comenzó de hecho, para venir más adelante a comenzar en teoría» ${ }^{5}$.

Pacheco exponía así su visión de lo acaecido en torno a las Cortes de Cádiz destacando la superación de las teorías por la fuerza del sentimiento nacional y espontáneo ${ }^{6}$ que emerge frente a la invasión francesa y que, inevitablemente, de-

${ }^{4}$ Es bien conocida la profunda crisis social y pérdida de toda legitimidad de los dos estamentos hasta entonces dominantes. Así, por todos, PACHECO, J. F., (1841) Historia de la Regencia de la Reina Cristina. Madrid, Imprenta de don Fernando Suárez, 1841. Tomo I, p. 27: «Lo mismo que con el clero acontecía con la nobleza aristocrática. La irrupción de las clases inferiores en los Títulos de Castilla había sido escandalosa desde la mitad del siglo XVIII. A millares se habían creado estos últimos durante cada reinado de aquella época. Concediéndolos de ese modo, casi sin motivo que alegar, y aun en muchos casos puramente por dinero, como se enajena un mueble o una finca, todo el prestigio moral de la nobleza, todo el poder moral que anteriormente había conservado acababa de desvanecerse en aquel diluvio de vulgaridad...».

5 PACHECO, J. F., (1841) Historia de la Regencia..., ya cit., Tomo I, pp. 55-56.

${ }^{6}$ La distinción que suele establecerse entre el doctrinarismo revolucionario continental, plagado de creaciones teóricas y el pragmatismo de la experiencia constituyente norteamericana, halla en nuestro 2 de mayo una curiosa excepción. Si, ciertamente, es peculiar y no alcanza permanencia por el respeto mantenido a la institución monárquica, no puede desconocerse, no obstante, la espontaneidad del fenómeno que da vida a la Nación española sin perjuicio de otros intentos precedentes. SEVILLA ANDRÉS, D. (1974) Historia Política de España (1800-1973), vol. I, $2^{\text {a }}$ ed. Madrid, Ed. Nal., p. 30) se refiere al Motín de Aranjuez como la primera manifestación práctica de la idea de Nación: En «Introducción» a Constituciones y otras Leyes y Proyectos Políticos de España. Madrid, Ed. Nacional, 1969, Tomo I, p. 11: «La burguesía, todo lo modesta que se quiera pero burguesía, ha cogido las riendas del poder en Aranjuez y, sólo, mientras la fuerza popular de la guerra impide su libertad de movimientos se somete a la revolución nacional...». 
jará sus huellas en el texto constitucional que por ello resulta paradójico e impracticable en la medida en que, siendo fruto de un movimiento indiscutiblemente popular, sin embargo respetaba los tres grandes principios sobre los que se asentaba la sociedad española (Rey, Religión, Libertad): «No es tanto el poder de la razón, no es tanto el valor de una teoría, por bien imaginada que sea, que puedan suplir lo que han hecho los siglos, y se ha connaturalizado con las entrañas de la sociedad ${ }^{7}$. Sin embargo, los tiempos eran otros y la emergencia de la nación española no iba a pasar desapercibida siquiera en el texto fundamental: «Los legisladores españoles — dirá Salas—, tuvieron bastante prudencia y sagacidad para aprovechar la circunstancia de la imposibilidad en que se hallaba el Rey de oponerles la menor resistencia, y de un suceso desgraciado sacaron un partido ventajoso, que no se hubiera sacado de la prosperidad. Probablemente sin la cautividad del Rey aun se hubieran pasado muchos siglos antes de que España tuviese una Constitución política y dejase de ser regida por la voluntad despótica de sus reyes y de sus ministros» ${ }^{8}$.

Pues, las ideas que se van difundiendo (como en el resto de Europa ${ }^{9}$ ) distan mucho de ser las que antaño avalaban la patrimonialización del Estado por los monarcas: «... al ver la conducta de los pueblos parece que están resueltos a vengar su dignidad ultrajada, y reclamar sus derechos... Si no me equivoco, el reinado de la fuerza ha pasado para ser reemplazado por el de la justicia» ${ }^{10}$.

\section{Ideas constitucionales y primer constitucionalismo español}

En el Preámbulo de la Constitución de 1812 se contenía un doble principio en cierto modo incompatible (o, mejor dicho, compatible sólo a condición que la Monarquía se transformara, de absoluta en constitucional). Pues, si de una parte se invoca al Rey ausente, de otra, se sitúa a las Cortes generales y extraordinarias de la Nación española en el lugar y protagonismo que realmente estaban teniendo. Por ello el Preámbulo, como la Constitución, son revolucionarios y sólo podían sobrevivir si el Rey asumía el cambio trascendental, tal como con claridad lo expresaba don Ramón Salas: «Digámoslo con franqueza, y no te-

7 PACHECO, J. F., (1841) Historia de la Regencia., Tomo I, p. 70.

${ }^{8}$ para las escuelas de España. Madrid, Impr. De D. Fermín Villalpando, Tomo II, p. 18.

9 Sobre la influencia de las ideas liberales procedentes de Europa, MARTÍNEZ SOSPEDRA, M. (1978) La Constitución de 1812 y el primer Liberalismo español. Valencia, Cátedra Fadrique Furio Ceriol, pp. 15 y ss.

10 SALAS, R. (1821), Lecciones de Derecho Público Constitucional... cit., p. 19. 
mamos imitar la valentía con que los legisladores de España cercados en un rincón del mundo por egercitos extranjeros... se atrevieron a profesar a la faz del mundo y de sus tiranos las verdades más fuertes, y mas atrevidas, pero también mas importantes de la política. Los Reyes son Reyes porque los pueblos quieren que lo sean, y no hay más legitimidad que la que viene de la voluntad del pueblo. Solamente un rey que apoya su poder sobre este fundamento debe creerse seguro en su trono, solo él puede llamarse rey legítimo.... ${ }^{11}$.

Nuestro primer constitucionalismo no está, por consiguiente, ayuno de ideas; pero sus circunstancias bélicas condicionaron irremediablemente la obra de las Cortes de suerte que, si partimos sólo de la consideración de los textos jurídicos, la contradicción que contienen no acaba de comprenderse bien. «En España no había sido hasta entonces el liberalismo una doctrina gobernante, ni había pasado de una oposición vaga, doctrinal, filosófica, excluida enteramente del poder...» por lo que resultaba lógico que no se temiera el desbordamiento de las pasiones democráticas como se temía al poder real. «La idea liberal, nueva, indefinida, inexperta, no podía ser otra que entrabar la autoridad del soberano, rodeándole de instituciones y cuerpos populares que impidiesen sus demasías» ${ }^{12}$. Para ello, sin embargo, sí existían suficientes bases doctrinales: «La labor de los por mí llamados «juristas de la revolución»... facilita el proceso de las Cortes de Cádiz que, al reunirse, ya encuentran establecido un orden revolucionario que se inició con la convocatoria de la Junta de Valencia para fortalecer y conseguir la unidad nacional» ${ }^{13}$.

La mayor fuerza de la reacción popular frente al invasor, en la que pierde protagonismo la que se hubiera podido llevar a cabo frente a su propio Rey, explica las contradicciones constitucionales criticadas por sus propios coetáneos. Así, describía Pacheco la situación: «Se ha acusado acerbamente a las Cortes por la declaración que hicieron el mismo 24 de setiembre, a las pocas horas de haber sido instaladas, acerca de la soberanía de la nación... Cualquiera que sea el valor filosófico de la soberanía nacional, la situación en que se hallaban las Cortes les imponía como un deber de honra el de proclamar aquel principio. Esa soberanía, declarada bajo el cañón francés, era sobre todo una protesta solemne contra la doctrina que hace a los pueblos propiedad y fundo de sus príncipes, y que

11 SALAS, R. (1821), op. cit., p. 10.

12 PACHECO, J. F., (1841) Historia de la Regencia...., Tomo I, cit., p. 67.

13 SEVILLA ANDRÉS, D. (1969), "Introducción» a Constituciones y otras Leyes..., ya cit., Tomo I, p. 11. La clasificación doctrinal de los diputados gaditanos puede hallarse es VARELA SUANCES, J. (1983), La Teoría del Estado en los origenes del constitucionalismo español (Las Cortes de Cádiz). Madrid, CEC, pp. 10 y ss. 
concede a éstos el derecho de enajenarlos según su voluntad.... Los que la han censurado olvidan que no se trataba entonces de proclamar principios filosóficos que fuesen ciertos sino de acordar medidas, ora de gobierno, ora de guerra, que fuesen útiles» ${ }^{14}$. Por ello, faltas de las condiciones y serenidad apropiadas para la conclusión de una obra sosegada, no puede exigírseles la coherencia propia de otras circunstancias. Por ello, recuerda también Pacheco, si aquel movimiento de la nación era magnífico y nada podía reemplazarlo para el fin que pretendían, «...necesario es advertir que estaba lleno de peligros para la suerte futura del Estado. La asonada de Aranjuez había conmovido el antiguo gobierno de las Españas: la marcha y abdicación de Fernando VII habían acabado de hecho con la monarquía: la insurrección de las provincias y la creación de sus Juntas levantaban en lugar de aquella una multitud de gobiernos populares, vagos e indefinidos, es verdad, pero reales y poderosos. El pueblo era, en toda su generalidad, con todo su carácter, quien se presentaba a luchar contra el que se decía sucesor en la corona; y si bien las autoridades que creó procedían en nombre del lejitimo monarca, ni tenían de éste su investidura, ni podía bajo ningún aspecto desconocerse la índole popular, en que consistían su orijen y su fuerza. La España en su gloriosa revolución de 1808 se vio repentina é inesperadamente convertida en un Estado popular y federativo» ${ }^{15}$.

Tal vez son las graves condiciones coyunturales aludidas con que se introduce el liberalismo en el constitucionalismo español lo que permite explicar que, de una parte, la Constitución de 1812 permanezca durante todo el siglo como un referente ideológico al que nunca podrá retornarse (además de haber constituido un referente internacional ${ }^{16}$ ) y, de otra, que a partir de tan simbólico texto, su

${ }^{14}$ PACHECO, J. F., (1841) Historia de la Regencia...., Tomo I, cit., pp. 61-62.

15 PACHECO, J. F. (1841), op. cit., p. 53. Pese a todo ello, ni la debilidad del asentamiento ideológico previo ni el desgaste del rechazo a la invasión impiden la identificación de las ideas revolucionarias francesas con los propios problemas sociales que los españoles vivían. Así se explica que nuestra Constitución no dejara de inspirarse en el constitucionalismo francés aunque en su empeño de conservar la monarquía y la religión asumió como pilares principios contradictorios. Sobre las influencias francesas es clásica la referencia a TORRES DEL MORAL, A. que ofrece una síntesis de sus estudios doctorales en Estado de Derecho y Democracia de partidos. Madrid, Serv. Publ. Univ. Compl. 1991, pp. 51 y ss. Recientemente, TORRES DEL MORAL, A. «Elementos de la ideología constitucional y su difícil recepción en España», en Revista de Derecho Político UNED, núm. 75-76, 2009, pp. 630 y ss.

16 «Lo cierto es que la Constitución de Cádiz fue la carta magna de la revolución liberal europea hasta 1848. No sólo por el constitucionalismo hispanoamericano, sino desde Portugal a Rusia, el peso de la Ley Fundamental española de 1812 fue sensacional...», cfr. SEVILLA ANDRÉS, D. (1974), Historia Política... ya cit., Tomo I., p. 79. En el mismo sentido, TORRES DEL MORAL, A. «Elementos de la ideología constitucional...», cit., p. 653. 
suspensión (en 1814 y 1823) o su reposición (en 1820) se lleven a cabo por el único medio posible: la imposición coactiva de uno de sus principios inspiradores sobre el otro por tratarse de principios entonces inconciliables e iniciando así un atípico modo de adaptación constitucional que perdurará durante todo el siglo. Como, por lo demás, dicha situación anómala puede, también, explicar las contradictorias posiciones adoptadas por el texto fundamental. El análisis de la cuestión religiosa bien puede considerarse uno de los más significativos ejemplos que lo que ahora se trata de exponer.

En efecto, del primer Constitucionalismo español hemos de subrayar su carácter ético (artículos 13 y 6) e igualitario que se manifiesta, este último, en los decretos del año 10 que preceden la propia obra constituyente y por los que se declara la igualdad de todos los españoles peninsulares y ultramarinos, con el efecto de generar la nivelación tributaria y la libertad de imprenta así como la exención de las pruebas de nobleza para ingresar en las academias militares (por lo demás, sentir general en todo el movimiento constitucional que arranca con Santo Tomás y se desarrolla a través de la escuela española del Derecho Natural). En Europa el racionalismo, abandonando, o reformulando el iusnaturalismo ${ }^{17}$, concilia también su sentir ético tal como se manifiesta, en concreto en Rousseau, en el último capítulo de «El contrato social». Pero este ambiente y sentir igualitario y libertario que también se vive en España no es fácil de conciliar en la realidad con el artículo 12 (que consagra la unidad de religión y la intolerancia) de una Constitución que, además, se abre con la invocación trinitaria. Al propio Argüelles no pasa desapercibida la contradicción que después explicará de este modo: «... Se consagraba de nuevo la intolerancia religiosa y lo peor era que, por decirlo así, a sabiendas de muchos que aprobaron con el más profundo dolor el artículo 12. Para establecer la doctrina contraria habría sido necesario luchar frente a frente con toda la violencia y furia teológica del clero... Por eso se creyó prudente dejar al tiempo... que corrigiera, sin lucha ni escándalo, el espíritu intolerante que predominaba en gran parte del estado eclesiástico $^{18}$.

Observando, pues, la consagración que la Constitución de 1812 lleva a cabo de la confesionalidad estatal y de la intolerancia religiosa no podría con-

17 Una breve síntesis de estas corrientes de pensamientos la realizada por FERNÁNDEZ SARRASOLA, I. (1996-97), «Estado, Constitución y forma de Gobierno en Jovellanos», en Cuadernos de Estudios del siglo XVIII, núms. 6 y 7. Oviedo, Instituto Feijoo de Estudios del siglo XVIII, pp. 81 y ss.) con el fin de situar el entorno en que se desarrolla el pensamiento de Jovellanos.

18 La reforma constitucional de Cádiz. Madrid, 1970, p. 263. 
cluirse que fuera ello (tal como se repite por doquier) lo que dejó planteada la cuestión religiosa que marcará todo nuestro siglo XIX; el duro enfrentamiento que ya entonces se vive en las Cortes y la protesta de los Prelados en ellas no deriva del texto literal sino más bien, dirá Sánchez Agesta ${ }^{19}$, del ambiente impreciso, consecuencia de la libertad de imprenta, que aunque limitada por la Constitución a la órbita política, en la práctica apuntó una audacia libelista que pronto comenzó a herir los sentimientos religiosos...». Ciertamente, el ambiente ilustrado y racionalizador dio vida, en España como en el extranjero, a una nueva fuerza social que, vinculada al ascenso de la burguesía, contribuye decididamente en el reforzamiento del fenómeno secularizador favoreciendo el establecimiento de la tolerancia y constituyendo a partir de entonces un referente invocado (con mayor o menor sinceridad) por los propios poderes públicos como fuente de legitimidad ${ }^{20}$ para una nueva concepción del Estado vinculada a la idea de publicidad ${ }^{21}$. Se trata de la opinión pública en torno a la cual se va generando una nueva dimensión de los derechos que llegará hasta nuestros días, la de su funcionalidad política o institucionalización. Por ello, subraya Sánchez Agesta ${ }^{22}$ la doble dimensión con que se reconoce la libertad de imprenta por las Cortes de Cádiz: en primer lugar, como función pública (y no como derecho individual) al servicio de la opinión y, en segundo lugar, como instrumento excepcional para controlar el poder de los gobernantes: «Pero esta función pública de la libertad de imprenta tiene un sentido más profundo. La libertad de imprenta como órgano de la opinión pública es un elemento básico de un régimen fundado en la soberanía nacional: y aún algo más, es una pieza de un régimen de publicidad que debe informar toda la vida del Estado ${ }^{23}$.

19 SÁNCHEZ AGESTA, L. (1972), Historia del Constitucionalismo español. Madrid, p. 106.

${ }^{20} \mathrm{Su}$ vinculación al movimiento ilustrado es obvia. La necesidad de conocer lo que piensan los ciudadanos, impone el cuidado de educación o formación política, como ya anticipara Cabarrús. El soberano, asegura Canga Argüelles, no puede desprenderse del poder de «arreglar la forma de las enseñanzas públicas para que haya unión de ideas de los ciudadanos y para que aquellas sean útiles a la patria y dignas de la grandeza del hombre». SEVILLA ANDRÉS, D. (1975), Orígenes de la Crítica social en España (1800-1856). Valencia, Cátedra Fadrique Furió Ceriol, p. 29.

${ }^{21}$ La opinión pública, afirmaba Sevilla Andrés, ilustrando su afirmación con la trascripción de muchas citas que la avalan), adopta ese aire de sanción al gobernante sustituyendo a la tradicional religiosa. Orígenes de la crítica..., cit., p. 29.

${ }^{22}$ Historia del Constitucionalismo..., ya cit., pp. 103 y ss.

${ }^{23}$ Ibidem, No en vano POSADA, A. (1894) (Tratado de Derecho Político, Madrid, Librería de Victoriano Suárez, pp. 456 y ss.) parte del análisis de la opinión pública como elemento esencial de los nuevos gobiernos para, desde la misma, analizar las libertades públicas clásicas tal como luego expondré. 
En el mismo sentido (de paulatino asentamiento de nuevas bases para la convivencia política que cuajan en una nueva concepción del Estado y, por consiguiente, de sus relaciones con los ciudadanos) cabe entender el encendido debate que, sobre la Inquisición, sostienen las Cortes gaditanas; es un debate cuajado de referencias a los conceptos de competencia y jurisdicción en las que, una vez más, el Estado trata de sobreponerse a las competencias de la Iglesia. Ni para los más decididos defensores de la supresión del Santo Oficio existe duda sobre la consagración de la unidad religiosa ni sobre la tipificación del delito de herejía, pero la cuestión era jurídico política: la atribución al Estado de toda competencia temporal que, sin lugar a dudas, la Inquisición había estado aplicando so pretexto de ejercicio de funciones espirituales. Si a ello se suma la no confesada pero muy sentida y difusa prevención frente a la preeminente e influyente situación del clero en el régimen social que se desea abandonar, se comprende la semilla sembrada por las Cortes de Cádiz para todo el constitucionalismo español pues «la línea que va desde aquí a Mendizábal y el anticlericalismo de progresistas y radicales puede dibujarse sin esfuerzo" ${ }^{24}$. No en vano Torres salva el aparente integrismo religioso (que supondría incompatibilidad con democracia) de la Constitución de 1812 al considerarlo una "estrategia política»" ${ }^{25}$.

Íntimamente unida a la idea de publicidad se va asentando una idea de instrucción que, si también procede de la Ilustración, tiene una nueva acepción política, de conocimiento de la cosa pública ${ }^{26}$. Tampoco ello pasó desapercibido para los constituyentes que trataron de formalizar tal doctrina en el propio texto constitucional. La idea, aún fracasada la Constitución de Cádiz, siguió pesando en las actuaciones del Trienio Libera ${ }^{27}$ y aún después como se pone de re-

${ }^{24}$ SÁNCHEZ AGESTA, L. (1972), op. cit., p. 113.

25 TORRES DEL MORAL, A. (2009) «Elementos de la ideología constitucional...», cit., p. 637.

${ }^{26}$ Aunque en el epígrafe siguiente volveremos sobre el tema, no puede ahora dejar de mencionarse la insistencia con que Martínez Marina se refiere a la necesidad de desarrollar los estudios políticos para que realmente se asienten las ideas liberales que en la obra de las Cortes de Cádiz se contienen. En Teoría de las Cortes o Grandes Juntas Nacionales de los Reinos de León y Castilla. Monumentos de su Constitución politica y de la soberanía del pueblo. Con algunas observaciones sobre la Ley Fundamental de la monarquia española, sancionada por las Cortes Generales y extraordinarias, y promulgada en Cádiz a 19 de marzo de 1812. Madrid, en la Imprenta de Collado. Año de 1812, p. LXXVI y ss.

27 BLASCO GIL, Y. (2000), La Facultad de Derecho de Valencia durante la Restauración (1875-1900). Universitat de Valencia, p. 35: Cádiz, dirá la Dra. Blasco, «no llegó a aprobar su proyecto de instrucción pública de 1814 — por la vuelta de Fernando... En el Trienio, en 1821, sí se llegó a aprobar un reglamento general de instrucción pública donde se regulaban los diversos estratos de la educación desde la primaria a la universidad» aunque fuera derogado con el fin del Trienio. 
lieve, por ejemplo, en Salas o en Jaumeandreu. De ahí, la significación de los artículos 366 y siguientes de la Constitución, dedicados a la instrucción pública. Tras el mandato de que se establezcan en todos los pueblos de la Monarquía escuelas de primeras letras, y de la obligación de explicar la Constitución en todas las Universidades y establecimientos literarios (sin que tampoco debamos pasar por alto la existencia de una Dirección General de Estudios, ni la atribución de competencia o reserva material a las Cortes), etc., el art. 371 cierra este Título dedicado a la instrucción afirmando que «todos los españoles tienen libertad de escribir, imprimir y publicar sus ideas políticas sin necesidad de licencia...» a modo de broche de oro que cierra el sistema basado en una opinión pública libre para un gobierno presidido por el principio de publicidad.

Así queda entendido por los publicistas de la época y así se explica incluso por los más pesimistas sobre las posibilidades de consolidación del régimen que ven, justamente en esta cláusula de cierre, la esperanza de que las nuevas ideas se difundan. Tal es la actitud y la esperanza de $S_{a l a s^{28}}$ que se muestra desconfiado de las restricciones e intervenciones publicas que se prevén para la enseñanza (creyendo él que ésta debió dejarse en absoluta libertad) así como de la eficacia de los buenos propósitos que el texto fundamental expresa en torno a la instrucción pública aunque es, justamente, en una buena organización de la pública instrucción donde, al cabo, puede situarse toda esperanza: «Dar una buena Constitución política no me parece sumamente difícil en un tiempo en que son ya tan conocidos los verdaderos principios de la ciencia social y los derechos del hombre; pero cuando se quiere poner en acción esta Constitución, empieza un combate terrible entre los intereses particulares y el interés general, y la victoria no se obtiene sin mucha constancia y energía, y sobre todo sin mucho tiempo, principalmente en un pueblo que no está preparado por las luces...».

\section{Periodo intermedio de aparente estancamiento}

La muerte de Fernando VII no comportó la vuelta a la efervescencia ideológica que se vivió en los dos períodos de vigencia de la Constitución de 1812. Sin embargo, sí se inicia con ella una obra de construcción técnica que resultará de gran utilidad en el futuro. Así lo afirma $\mathrm{Nieto}^{29}$ respecto de la labor realizada durante la Regencia de María Cristina, de gran interés en el campo admi-

28 SALAS, R. (1821) Lecciones de Derecho Público Constitucional para las Escuelas de España. Madrid, Imprenta de D. Fermín Villalpando, Tomo II, pp. 292-293.

${ }_{29}$ NIETO, A. (1996), Los primeros pasos del Estado constitucional. Barcelona, Ariel, p. 97. 
nistrativo, pero extraordinariamente negativa en punto a las libertades que habrán de esperar hasta el último tercio del siglo. Tanto el sistema administrativo como las relaciones entre el Estado y los ciudadanos se basaban en una peculiar concepción de los derechos políticos entendidos como obra o concesión del legislador, quien de esta forma estaba legitimado para establecer y alterar cualquier sistema con absoluta libertad ${ }^{30}$. La consecuencia o, mejor, la finalidad política de tal disquisición la extrae sin tapujos Alcalá Galiano: en última instancia, se trata de conceder un amplísimo margen al legislador por lo que «no puede haber ninguna injusticia en la concesión de derechos políticos: el legislador, por razones de conveniencia pública, es quien los concede o los niega» ${ }^{31}$. La manipulación, concluye Nieto, era fácil, bastaba con calificar de políticos los que realmente eran civiles ${ }^{32}$.

Así pues, el período cristino no es decisivo en materia de derechos ni determina avances en la concepción democrática; pero sí lo es en el asentamiento de técnicas jurídicas que con el tiempo permitirán un más fácil desarrollo de aquéllos. Por ello, concluye Nieto que en el período de la Regencia de María Cristi-

${ }^{30}$ Con razón recuerda Nieto que ésta era la posición rigurosamente mayoritaria de la época y, a modo de ejemplo cabe recordar una de sus múltiples citas: «Así lo teorizó Sancho (DSC, 1836, III, 78) al exponer con acento profesoral que «los derechos se dividen en civiles y políticos. Los civiles son de todos y corresponden a ambos sexos, a todas las edades, a ricos y a pobres, a grandes y a pequeños, de modo que pueda decirse en último análisis que son inherentes a todas las personas que existen en la sociedad. En orden a los derechos políticos y al ejercicio de las funciones activas que establecen, dependen de las disposiciones de la Ley: ésta los da; al paso que los derechos civiles, si bien se gozan al amparo de la ley, arrancan del origen de las sociedades».

${ }^{31}$ DSC, 1836, III, 197, cit. por NIETO, A. (1996), La posición de ALCALÁ GALIANO en esta ocasión es absolutamente coherente con sus planteamientos de rechazo a las nuevas teorías referidas a los derechos frente a las que muestra sus reticencias en sus Lecciones de Derecho Politico Constitucional (Madrid Imprenta de D. I. Boix, (1843). Así, se lee en p. 74, sobre su inquietud ante lo que cree es un arrinconamiento de la religión: «...el reconocimiento solemne de ciertos derechos, proclamados por varios publicistas como inherentes al hombre, y intitulados sagrados e imprescriptibles, si bien por desgracia lo sagrado les venía del intento de sustituirlos a la dignidad e importancia de la religión entonces algo desconocida...», y en p. 93 sobre los nuevos derechos en general: «...Al lado de la seguridad personal está la seguridad pública, y si bien de la segunda suele ser la primera una parte y no corta, ocasiones hay en que a la segunda se opone el que gocen algunos de los súbditos de aquella otra con latitud suma...». Tras ir manifestando sus reparos con los nuevos derechos se pregunta sobre qué principio general se podría sustentar el edificio constitucional, para concluir (en p. 96) que «...hay uno sobre el cual han estado fundados algunos gobiernos en la antigüedad y este es el de la religión. Por desgracia, señores, no estamos en tiempos en que pueda establecerse una constitución sobre un principio religioso, dando así a las leyes la sanción más alta. Pero conozcamos y confesemos que las constituciones cimentadas en un principio superior a todos, como es la religión, estribaban como en una roca incontrastable...».

32 NIETO, A. (1996), op. cit., pp. 97-98. 
na, pese a las dificultades de la guerra, el Boletín Oficial siguió trabajando y llegó a crearse un Estado nuevo pero sólo sobre el papel ${ }^{33}$. Y ello no fue trabajo perdido pues pudo retomarse con posterioridad por los moderados que encontraron, así, el camino del Estado Constitucional allanado. Lo que llama la atención a Nieto es que, siendo ya ésta una tarea ardua y más que suficiente, los liberales pretendieran mas aún, que además de ocuparse de la guerra y de poner en pie un Estado nuevo, quisieran, también, hacer una revolución ${ }^{34}$.

Volviendo a la consideración de los textos fundamentales ${ }^{35}$, de la Constitución de 1837 bastará con recordar sólo alguna idea que la sitúa a medio camino entre el constitucionalismo gaditano y el revolucionario que se consagra en la Constitución de 1869, tras el forzado exilio de Isabel II. La sola comparación del Preámbulo de Cádiz con el de esta Constitución del 37 permitiría sacar consecuencias sobre el cambio de referencias en cuanto a los principios ideológicos y al respectivo ambiente político en que una y otra se inspiran; sin embargo, no puede desconocerse el interés ideológico de esta Constitución del 37 que rompe con el estancamiento que tras la muerte de Fernando VII da paso al Estatuto Real y decanta a la monarquía a una opción liberal, inevitable por lo demás, si consideramos el estallido de la Guerra Carlista por la sucesión en el Trono y el tradicionalismo que D. Carlos encarna.

En efecto, aunque la Constitución ${ }^{36}$ se encabece con el nombre de la Reina niña y de su madre como Regente, no pasan desapercibidas otras menciones: "Que las Cortes generales han decretado y sancionado, y Nos de conformidad aceptado, lo siguiente: Siendo voluntad de la Nación revisar, en uso de su soberanía, la Constitución política promulgada en Cádiz...». Sobre ser la primera Constitución española que incluye en su mismo texto la declaración de derechos, la referencia a la de Cádiz es muy significativa ${ }^{37}$.

33 «La obra administrativa... causa asombro por la enormidad de sus proporciones. En siete años mal contados se creó febrilmente un Estado moderno hasta en sus últimos detalles... Pero fue una construcción ficticia que en sus elementos esenciales no llego a encanarse en la realidad. Nada fue ejecutado del todo ni casi nada podía cumplirse puesto que todas las energías y toda la autoridad del Estado se desviaban hacia la guerra... La historia administrativa de la Regencia de María Cristina deba entenderse como el boceto de un edificio gigantesco y moderno trazado por arquitectos administrativos de excelente formación pero que no pudo ser construido en aquel momento».

${ }^{34}$ NIETO, A. (1996), op. cit., pp. 41 y ss.

35 TORRES DEL MORAL, A. (2009) «Elementos de la ideología constitucional...», cit., p. 638: Pese a la coincidencia en que los llamemos Constituciones, no todos ellos merecen, en puridad, tal nombre. Salvo que aceptemos que existen varios grados o niveles de constitucionalismo.

36 Texto en SEVILLA ANDRÉS, D. (1969), Constituciones... ya cit., Tomo I, pp. 325 y ss.

37 En este proemio cifra Jaumeandreu el núcleo de toda la Constitución: «Contestando, pues, al deseo justo que se expresa, y habiendo ya explicado en que consiste la soberanía, vamos a de 


\section{El liberalismo doctrinario de la Constitución española de 1845 y el fracaso del Bienio progresista}

Tal vez el alcance real que en el plano político alcanza la Constitución de 1837 como texto de partido como mejor se pone de relieve es con la lectura del Dictamen ${ }^{38}$ sobre la reforma de la misma que daría paso a la Constitución de 1845. Y tal paso es muy significativo pues se trata de consagrar el liberalismo doctrinario que ya se anuncia explícitamente en el citado Dictamen: «La potestad constituyente no reside sino en la potestad constituida, ni esta es otra que en nuestra España sino las Cortes con el Rey»... La Comisión la ha aceptado y la proclama aquí con un profundo acatamiento. Las Cortes con el Rey son la fuente de las cosas legítimas: su potestad alcanza a todo, menos a aquellas leyes primordiales contra las cuales nada puede intentarse que no sea nulo de toda nulidad, porque son como los fundamentos de las sociedades humanas...».

Con semejante, y tan conservadora, prevención frente al texto de 1837, es fácil adivinar el carácter de la futura Constitución española de 1845. El Dictamen irá desgranando todas las prescripciones que resultan intolerables para la majestad de la institución monárquica o para la conservación de fueros de clase y privilegios que eliminó la de 1837. Es precisamente esta fundamentación conservadora del texto de 1845 la que permite explicar el contenido y significación del precepto que dedica a la cuestión religiosa: «La religión de la Nación española es la Católica, Apostólica y Romana. El Estado se obliga a mantener el culto y sus ministros» (reza el art. 11 de la Constitución de 1845). Tal vez, pues,

mostrar con toda la claridad posible que dicha soberanía no reside exclusivamente en el monarca, sino en toda la nación... Si los españoles no disfrutaran de la preciosa facultad de legislar, que es como tenemos dicho, el principal atributo de la soberanía, ¿cómo pudieran asegurar su bien estar no siendo entonces dueños de su voluntad y no conservando siempre el derecho de establecer cuanto conduzca al bien general?... Reside, pues, la soberanía en el cuerpo de la nación. Ella está incorporada en el pueblo, y el interés del pueblo en la soberanía. En una palabra: un pueblo libre e independiente es un pueblo soberano... Cuando un pueblo se constituye, da la ley, que no la recibe, y si de alguna parte la pudiera recibir, sería de su voluntad, de su razón, de su interés, de su conveniencia, y la consecuencia inmediata de la soberanía nacional es, que los pueblos formen sus constituciones y no las reciban de los monarcas al placer y voluntad de estos..." JAUMEANDREU, E, (1839), Catecismo razonado ó explicación de los artículos de la Constitución Política de la Monarquia Española, publicada en 18 de junio de 1837. Barcelona, Imprenta de Tomás Gaspar, pp. 34-35.

38 Dictamen de la Comisión sobre la reforma de la Constitución de 1837 (5 de noviembre de 1844), en Donoso Cortes, Obras ordenadas y precedidas de una noticia biográfica por D. G. Tejado. Madrid, Imprenta de Tejado, 1854, Tomo III, pp. 61 y ss. También en Sevilla Andrés, Constituciones... ya cit., Tomo I, pp. 307 y ss. 
para el proceso secularizador y su institucionalización pública, lo más significativo de este período intermedio es el clima de ideas y convicciones que hallan ocasión de recrearse en el Bienio progresista aunque no alcancen eficacia alguna jurídica por haberse reflejado precisamente en la Constitución que no llegaría a nacer: Constitución «nonnata» de 1856. En ella resulta innegable el acuerdo por recuperar los planteamientos políticos de 1837 puestos de relieve en el Dictamen de la mayoría de la Comisión acerca de las Bases de la Constitución ${ }^{39}$ y perfectamente sintetizados en el breve Preámbulo de la nonata: «Las Cortes constituyentes, en uso de sus facultades, decretan y sancionan la siguiente Constitución de la Monarquía española».

El proyecto radical sigue, pues, sin posibilidad de triunfo alguno hasta el ya próximo Sexenio revolucionario. Y ni siquiera entonces acaba de cuajar por lo que, para hallar en la práctica un cierto asentamiento de las ideas liberales tendremos que retomar el subsiguiente período conservador pues la breve experiencia revolucionaria del sexenio acabará poniendo de relieve, como recuerda Suárez Cortina ${ }^{40}$, la necesidad de «...una refundación de las propuestas, centrando su interés en la redefinición de los distintos proyectos sociales y políticos bajo el sello de la República, la atención preferente a la difusión de los ideales democráticos mediante el impulso de diversas iniciativas culturales, ....y la aclimatación a una nueva cultura política, menos afín al utopismo revolucionario, al motín y al levantamiento militar y, de un modo gradual y no exento de tensiones, afecta a la participación electoral y a la movilización pacífica de la ciudadanía» ${ }^{41}$.

\section{Ultimo tercio del siglo; especial significación del periodo de la Restauración}

No es la primera vez que intento subrayar la importancia del paso que en el último tercio del siglo XIX se da en la consolidación del Derecho Público, bien por mor de las políticas aperturistas que lentamente se introducen en España, bien por las ideas, ya propias, ya ajenas, que las inspiran y, naturalmente,

39 Puede verse, con los votos particulares al mismo, en SEVILLA ANDRÉS, D. (1974) Constituciones..., ya cit., TOMO I, pp. 433 y ss.

${ }^{40}$ SUÁREZ CORTINA, M. «Liberalismo, democracia y República en la España Contemporánea. Una perspectiva histórica», en SÁNCHEZ FERRIZ, R. y GARCÍA PECHUAN, M. (coords.) La enseñanza de las ideas constitucionales en España e Iberoamérica. Valencia. 2001. Colección Ideas y Políticas Constitucionales, n. ${ }^{\circ} 1$.

${ }^{41}$ Aspecto, éste, que subrayo por mi parte por lo que luego he de decir sobre el período restaurador y sobre el papel que en la democratización del Estado tendrán las libertades públicas. 
con la imprescindible apoyatura de las técnicas jurídicas que desde tiempo atrás se han ido implantando en nuestras instituciones ${ }^{42}$. Respecto de éstas, las diversas referencias ya hechas a la obra de Nieto sobre la conformación de las técnicas administrativas propias del Estado contemporáneo ya en el período cristino son bien reveladoras. En cuanto a la evolución de las ideas o, mejor, su progresivo aunque lento asentamiento, baste con recordar el papel que también supra se subrayó para la libertad de imprenta. Desde su reconocimiento en las Cortes de Cádiz siempre fue considerada un hito en el proceso de liberalización de la cultura y, por consiguiente, de secularización, hasta alcanzar en el período final del siglo XIX una extraordinaria influencia política que permitía afirmar a Posada ${ }^{43}$ que «La libertad de prensa, en cuanto significa y supone la abolición del procedimiento inquisitorial y de previa censura, y la sumisión al régimen represivo, puede considerarse, según afirman Bluntschli y Seydel, como Estado de Derecho en los pueblos civilizados de Europa y América».

4.1. Junto a las técnicas jurídicas del Estado de Derecho, alumbran las de naturaleza democrática

En los últimos años del siglo nos encontramos, pues, con el momento histórico en que, cuajando los precedentes a que se ha ido haciendo referencias, se agota una etapa del constitucionalismo, para iniciarse otra. En este sentido, observa Clavero ${ }^{44}$ que es en este período cuando se opera el distanciamiento entre dos esferas de intereses hasta entonces unidas: los intereses estrictamente políticos y los de clase (representados éstos por los derechos privados que los códigos se ocupan de regular). «Nuestro Código civil de 1888, escribe Cascajo, se transforma en el sucedáneo auténtico de la Constitución y como tal se le apro-

42 SÁNCHEZ FERRIZ, R, "Derechos y Libertades en el último tercio del siglo XIX», en Estudios en Homenaje al Profesor J. Tomas Villarroya, Cuadernos Constitucionales Fadrique Furió Ceriol, Universidad de Valencia, n. ${ }^{\circ}$ 9-10. SÁNCHEZ FERRIZ, $\mathrm{R}$ "Aproximación a la difusión de las ideas constitucionales en España y su configuración como disciplina jurídica en el siglo XIX» en SÁNCHEZ FERRIZ, R. y GARCÍA PECHUAN, M. (coords.) La enseñanza de las ideas..., cit. (pp. 63-106). SÁNCHEZ FERRIZ, R (2007) «Significación histórica de las Libertades Públicas. Su configuración doctrinal en el período de la Restauración", en VV.AA. Derecho, Historia y Universidades. Estudios dedicados a Mariano Peset. Universitat de Valencia (pp. 617 a 632).

43 POSADA, A. (1841), Tratado de Derecho Político, Madrid, Librería de Victoriano Suárez, 1894 , p. 441, Historia de la Regencia de la Reina Maria Cristina. Madrid, Impr. De D. Fernando Suárez, Tomo I, p. 491.

${ }^{44}$ CLAVERO, B. (1984), Evolución histórica del constitucionalismo español, Tecnos, Madrid, pp. 98-100. 
vecha, coartada para juristas y acomodo para jueces» ${ }^{45}$. Ello no obstante, y volviendo a la afirmación de Clavero, en este último tercio de nuestro siglo XIX el régimen constitucional va autonomizándose ${ }^{46} \mathrm{y}$ generando su propia dinámica en la medida en que comienzan a reconocerse, aún con muchas limitaciones, los derechos de carácter colectivo y de trascendencia pública hasta el punto de provocar la democratización del régimen y, a la larga, una profunda transformación de las instituciones.

Es precisamente, como afirma Clavero, la consagración constitucional de las libertades públicas, junto a la ampliación del sufragio, que se operan a partir de la revolución de 1868 , lo que permite la desconexión entre el modelo político y el social hasta entonces unidos: «Las libertades públicas y el sufragio general propiamente conducían a la estructuración de un orden político independiente, en cuanto tal, del referido modelo social, bien que esto distase de constituir un efecto inmediato de la misma Constitución y mas aún en el caso de una tan precavida en este terreno como la de 1976 que habría de regir aquí este proceso» ${ }^{47}$.

\subsection{Dimensión social del Estado constitucional}

En realidad, es el propio Estado el que está evolucionando a la par que los nuevos modos políticos por obra de los movimientos sociales y del cambio de mentalidad que entrañan. A fin de siglo escribía Posada ${ }^{48}$ sobre la Administración social subrayando las nuevas funciones que el Estado había asumido a medida

45 CASCAJO CASTRO J. L. (1990), «Acerca de los derechos fundamentales en el constitucionalismo histórico español», Debate abierto. Revista de Ciencias Sociales, n. ${ }^{\circ} 2$, p. 113 . El régimen canovista representa la culminación del enfoque privatista y burgués de la sociedad que, rechazando toda libertad con trascendencia pública, garantiza la paz social y las relaciones civiles y mercantiles; no en vano, junto al mencionado Código civil, proceden del mismo período el Código de comercio (1885) y la Ley de Enjuiciamiento civil (1882) entre otros cuerpos legales que han pervivido hasta nuestros días.

46 Asimismo en este mismo periodo (concretamente en el último cuarto del siglo) sitúa PORTERO, J. A. (1980) («Algunas cuestiones en el Derecho Político español. 1875-1900», en REP, n. ${ }^{\circ} 18$ (Nueva época), Madrid, pp. 71 y ss.) la configuración del Derecho Constitucional propiamente dicho.

${ }^{47}$ CLAVERO, B. (1984), op. cit., p. 100. De ahí, la afirmación que en otras ocasiones he formulado sobre la inconveniencia de incluir, como mayoritariamente se viene haciendo, en una sola generación de derechos (la considerada como primera) tanto los derechos civiles como los políticos y las libertades públicas pues entre unos y otros no solo hay una diferencia de estructura y funcionalidad 51 sino, también, una diferente concepción del constitucionalismo y del Derecho Público general. Vid mi libro Estudio sobre las libertades. Tirant lo Blanch, Valencia, 1995.

48 POSADA, A. «La Administración Política y la Administración Social. Exposición crítica de las teorías y legislaciones administrativas modernas mas importantes». Madrid, La España Moderna, p. 419. 
que el fenómeno secularizador se había extendido: «La transformación social que caracteriza la vida moderna, y que pudiéramos clasificar como transformación en el sentido de la secularización de la vida, ha traído al Estado grandes sumas de medios y grandes energías espirituales, así como ha infundido en él el alma de la civilización, sumando en sus gobiernos los más altos poderes de cada sociedad. Ahora bien, esto ha determinado un radical cambio de posición en las fuerzas de los pueblos; y así, por ejemplo, muchos de los fines sociales que antes eran cumplidos por la Iglesia, hoy son cumplidos por el Estado ¿Por qué? Porque este es, hoy por hoy, la personalidad más saliente, más poderosa, y, por ende, más obligada para con la humanidad de cuantas existen. De este modo se explica cómo poco a poco, seguin se va formando el Estado constitucional representativo, a pesar de que se acentúa cada vez con mayor intensidad la personalidad humana individual, y se afirman sus derechos todos, el Estado haya aumentado en cierto sentido su esfera de acción ${ }^{49}$.

Pero tampoco la cuestión social era entonces desconocida ni novedosa por más que hoy estos conceptos nos resulten tan actuales; aunque ciertamente en formas, estilos e intereses muy distintos, todas las formulaciones de las que nos hemos servido en el siglo XX eran bien conocidas en el XIX. Ya en las Cortes Constituyentes de 1854 se ponía de relieve la incongruencia con que se alegaban principios revolucionarios que en cierto modo ya eran obsoletos o, al menos, muy insuficientes: Sobre las Bases del texto constitucional que no llegaría a nacer se decía ante las Cortes (23.1.55): «No consignáis [en tales Bases] mas que la revolución política desentendiéndose completamente de la revolución social que llama a todas las puertas y conmueve a todos los pueblos de Europa... Los pueblos no sólo quieren derechos políticos; quieren, además, derechos sociales. Los derechos políticos les aseguran su dignidad, digámoslo así; los derechos sociales les aseguran el pan que necesitan para su subsistencia» ${ }^{50}$.

\section{EL DERECHO POLÍTICO-CONSTITUCIONAL EN LAS PRIMERAS MANIFESTACIONES DE LA MANUALÍSTICA}

Nuestra época es política; nuestra atmósfera intelectual y moral está completamente saturada con ese elemento; ni nuestra inteligencia ni nuestra voluntad pueden libertarse de su influjo, ni quedar exentas de su acción ${ }^{51}$.

${ }^{49}$ Los subrayados son míos por haber considerado que la claridad de la idea que en ellos se expresa sobre el cambio del Estado eximen de todo comentario.

50 Cit. por SEVILLA ANDRÉS, D. (1974), Historia política..., p. 204.

51 Joaquín Francisco PACHECO, J. F. (1858), «Separación del Derecho y la Política, Discurso inaugural en la Apertura de la Academia de Legislación y Jurisprudencia», en Literatura, His- 
Si estas palabras de Pacheco son ciertas y definen bien el siglo XIX, no lo es menos la extraordinaria dificultad con que acabará aceptándose la idea y todas sus consecuencias políticas; aquélla sufre todos los avatares de un siglo que, sobre ser de cambio profundo en la concepción del Estado, presencia varias guerras civiles. En tan complejo ambiente va tomando cuerpo, sin embargo, la disciplina que habrá de enfrentarse cara a cara con la realidad del poder para reconducirlo al Derecho; no es extraño, pues, que el armazón del futuro Derecho constitucional hubiera de armarse y desarmarse en varias ocasiones como en concreto sobre los distintos intentos de establecer la asignatura, puso de relieve Pérez Serrano: «Pese a los insistentes esfuerzos del Consejo Real para que en nuestras Universidades se estudiara el Derecho patrio... poco se había de lograr en este sentido hasta fecha realmente próxima. El Derecho Natural y el de Gentes se reputaban parte de la Teología aunque el Doctor Sancho de Moncada había propuesto en tiempos de Felipe IV para que se cree en el Colegio Imperial de Madrid, entre otras Cátedras, una de «Políticas y Económicas para interpretar a Aristóteles ajustando la razón de Estado con la conciencia, religión y fé católica».... La Cátedra fue reemplazada (al realizarse la expulsión de los Jesuitas que regentaban aquel Colegio) por otra de Derecho Natural y de Gentes; pero no más tarde que en 31 de julio de 1794, el Rey Carlos IV suprimió en todas las Universidades, Seminarios y Estudios las Cátedras de Derecho Político y del Natural o de Gentes, según explica Lafuente, por causa de las malas doctrinas, textos depravados e ideas sediciosas y ateas de muchos Catedráticos ${ }^{52}$.

\section{Catecismos para dar a conocer la Constitución}

Del ambiente gaditano ya descrito resulta fácil deducir el peso extraordinario de sus aportaciones que, desde el punto de vista doctrinal, cabe centrar en Jovellanos $^{53}$, Martínez Marina y Salas. Es éste el que, sobre ofrecer una ajustada definición del Derecho constitucional: «El nombre de derecho constitucional conviene mejor que el de público... porque el adjetivo público puede confundir al derecho lla-

toria y Politica, TOMO II, Madrid, 1864, p. 251. Sobre las diversas interpretaciones ideológicas de los principios básicos del Estado de 1812 es decisiva la consulta de VARELA SUANCES, J. (1983), La Teoría del Estado en los orígenes del constitucionalismo español (Las Cortes de Cádiz) ya cit.

52 PÉREZ SERRANO, N. (1976) Tratado de Derecho Político. Madrid, Civitas, p. 67.

53 Por todos, y entre tantas obras que la Cátedra de Oviedo sigue dedicando al pensamiento de la época, una espléndida síntesis de las interpretaciones del pensamiento de Jovellanos es la ofrecida por FERNÁNDEZ SARRASOLA, I. (1996-97), "Estado, Constitución y forma de Gobierno..." ya cit., pp. 77 y ss. 
mado de gentes con el derecho constitucional y en nada se parecen estos dos derechos: pues el llamado muy impropiamente derecho de gentes no es en realidad más que una colección de pactos y tratados... el derecho constitucional es el que arregla las relaciones entre los gobernantes y los gobernados, distribuye los poderes políticos de la sociedad y prescribe el modo de ejercerlos. Yo he adoptado la denominación complexa de derecho público constitucional, porque me parece que previene todo equívoco.... ${ }^{54}$.

Pero la obra doctrinal no sigue a las Cortes sino que las precede; baste pensar que las primeras de ellas, significativas, ya se publican en 1808, cual es el caso de las de Martínez Marina o de Jovellanos (cuya desvinculación del despotismo y talante próximo al liberalismo ha sido recientemente reivindicado $o^{55}$ aunque, realmente, lo que represente sea un precedente del liberalismo doctrinario). La preocupación pedagógica de Martínez Marina es declarada: al observar, explica, una serie de «síntomas ${ }^{56}$ que anunciaban la proximidad o de una extraordinaria revolución en España o de grandes mudanzas y reformas en su constitución y gobierno entendió que convenía mucho difundir las luces, preparar la nación e instruir al pueblo». Y así explica sus publicaciones: «Con este fin publiqué en el año 1808 el Ensayo histórico-crítico sobre la antigua legislación de los reinos de León y Castilla...." ${ }^{57}$.

54 SALAS, R. (1821), Lecciones de Derecho Público..., ya cit., pp. 3-4.

55 FERNÁNDEZ SARRASOLA, I. (1996-97), «Estado, Constitución y forma de Gobierno...» ya cit. en pp. 116-117: «...las leyes no las elaboraba sólo el Parlamento, sino también el Monarca... por lo que el concepto de voluntad general que utiliza Jovellanos no es idéntico al rusoniano... Desde esta perspectiva no podría definírsele como un liberal en el mismo sentido que se utiliza para designar a sus coetáneos partícipes en la elaboración de la Constitución de Cádiz... Creemos, concluye el autor en p. 118 «que Jovellanos sería tan sólo un liberal si se entiende a la inglesa y en la línea de Burke, al que vinculaba la idea de Constitución histórica, el rechazo del valor absoluto de la razón, la negación de los «derechos naturales», en fin, su actitud crítica hacia el proceso revolucionario francés».

56 MARTÍNEZ MARINA, F. (1812), Teoría de las Cortes o Grandes Juntas Nacionales de los Reinos de León y Castilla. Monumentos de su Constitución política y de la soberanía del pueblo. Con algunas observaciones sobre la Ley Fundamental de la monarquía española, sancionada por las Cortes Generales y extraordinarias, y promulgada en Cádiz a 19 de marzo de 1812. Madrid, en la Imprenta de Collado. Año de 1812, p. LXIV.

57 De ahí la necesidad de «preparar los espíritus, allanar los caminos, disipar los nublados, derramar las luces y fijar la opinión pública sobre las primeras verdades en que se apoyan los derechos del hombre y del ciudadano...» antes de intentar levantar el «magestuoso edificio de nuestra regeneración» sin dudar sobre el instrumento necesario que pueden poner en marcha quienes están capacitados para ello: Para la consecución de tan importante objeto mucho convendría publicar obras metódicas de moral y de política, propagar esta clase de conocimientos, darles la posible extensión y familiarizarlos en el pueblo. Hoy más que nunca debemos ocuparnos en el estudio de la 
Seguro del efecto positivo y transformador que es capaz de causar la instrucción pública, sostiene, sin embargo, que no cabe confiarlo todo a ella pues todos los medios son pocos para alcanzar el fin de establecer un nuevo Estado: «Así que, mientras llega el feliz momento en que se organice y se adopte un sabio sistema de instrucción pública, hasta tanto que las luces se difundan por todas las clases del Estado, es necesario apelar a otros recursos y oponer a la común dolencia diferente género de remedios, mayormente siendo cierto que el nuevo plantel de sabiduría no se puede perfeccionar de repente, que su fruto ha de ser siempre tardío y su influjo muy lento, y no es de esperar que logre disfrutar de él la generación presente.... ${ }^{58}$. La idea, difundida en la época entre los ilustrados, hallaba lógica acogida en el Discurso Preliminar a la Constitución de $1812^{59}$ : «El Estado, no menos que de soldados que le defiendan, necesita de ciudadanos que ilustren a la nación, y promuevan su felicidad con todo género de luces y conocimientos. Asi que uno de los primeros cuidados que deben ocupar a los representantes de un pueblo grande y generoso es la educación pública...».

En todo caso, y por lo dicho, lo más relevante del período son, sin duda alguna, las previsiones constitucionales contenidas en los artículos 366 y siguientes $^{60}$ cuya buena intención ya criticaba Salas poniendo de relieve la imposibilidad de su aplicación con la escasez de medios de que se disponía. Ello no obstante, existe constancia de su puesta en práctica en muchos lugares como pone de manifiesto Blasco Gil ${ }^{61}$ y, por supuesto, tuvo un inmediato efecto a nivel universitario con la creación de las Cátedras de Constitución de las Universidades de Madrid, Sevilla, Valencia y Granada que, pese a su efímera vida, enlazan, según Sánchez Agesta, por su contenido con lo que hoy es la ciencia del Derecho Constitucional». Ni tampoco es de olvidar que en el año 1812 se publica en Valencia la traducción del Contrato Social, bajo el título de Principios de Derecho

filosofía y de la moral pública, estudio abandonado y aún proscripto por la superstición y el despotismo...». MARTÍNEZ MARINA, F. (1812), Teoría de las Cortes o Grandes Juntas Nacionales de los Reinos de León y Castilla. Monumentos de su Constitución..., ya cit., p. LXXVII.

${ }_{58}$ MARTÍNEZ MARINA, F. (1812), Teoría de las Cortes o Grandes Juntas Nacionales de los Reinos de León y Castilla. Monumentos de su Constitución..., ya cit., p. LXXVIII.

59 Influido en este punto por el Informe de Quintana, al decir de Puelles (DE PUELLES BENITEZ, M. Educación e ideología en la España contemporánea (1767-1975), Ed. Labor, Barcelona, 1980 , pp. 55 y ss.).

${ }^{60}$ Un completo estudio de los preceptos y su aplicación en PESET REIG, M. y GARCÍA TROBAT, P. "La Constitución de 1812 o Cómo educar a un pueblo», en R. SÁNCHEZ FERRIZ... (coords.) La enseñanza de las ideas..., cit. (pp. 23 a 62).

${ }^{61}$ BLASCO GIL, Y. (2000), La Facultad de Derecho de Valencia durante la Restauración (1875-1900). Universitat de Valencia. 
Político y en Santiago se publica la traducción de la misma obra en el año 1813. Si ello es en sí mismo significativo, mayor calado, aunque sus efectos hayan de esperar años aún, tiene el conocimiento que de las nuevas ideas europeas tienen nuestros estudiosos tal como se pone de relieve en la lectura de sus obras.

No es de extrañar que, con la vuelta de Fernando VII, las intenciones pedagógicas de la Constitución y todo otro intento de establecer el Derecho Constitucional en las aulas siguieran la misma suerte que la obra general de las Cortes. Justamente al Sexenio Absolutista, en cuanto simboliza todo resto del Antiguo Régimen, se refiere Salas ${ }^{62}$ del siguiente modo: En las universidades estaba rigurosamente prohibida la enseñanza del derecho político de que ni aun se permitía hablar por incidencia: en algunas se establecieron cátedras llamadas de derecho natural y de gentes y aunque esta ciencia se enseñaba generalmente por libros y por maestros que no eran peligrosos para el despotismo y para la superstición, no tardaron el gobierno y la inquisición en conocer que saber el Heinecio o el Bourlamachi, ya era saber algo y se suprimieron aquellas cátedras apenas nacidas. Sin embargo, en ellas aprendieron los jóvenes destinados al estudio de la legislación, que había algo mas que saber... unos pocos maestros... se atrevieron a anunciarles algunas verdades nuevas para ellos, cuya importancia y evidencia picaron su curiosidad, y les movieron a buscar y leer algunos buenos libros a todo riesgo. Ya el Espíritu de las leyes de Montesquieu circulaba por las manos de muchos jóvenes... el Contrato Social se tradujo...los Tratados políticos del Abate Mabli eran bastante conocidos, y las obras del marques de Beccaria y las de Filanghieri....

Con la también efímera vuelta del Trienio al liberalismo se intentaría de nuevo consagrar el Derecho político en el nivel universitario con el Reglamento de Instrucción Pública de 29 de junio de 1821 creándose una Cátedra de Derecho Político de Europa en la Universidad Central. A partir de ahí, la disciplina irá apareciendo y desapareciendo de los Planes de Estudios según los avatares políticos de aquellos años para reaparecer definitivamente en el Plan Pidal de 1845 aunque unida al Derecho Administrativo. En el Plan de 1883 sigue contemplándose como Derecho Político y Administrativo. Se separan ambas ramas en el año 1900, en que ya aparece con carácter independiente el Derecho Político español comparado con el extranjero que en el Plan aprobado por Decreto de 11 de septiembre de 1931 ya adoptó la denominación de Derecho Político mantenida hasta la vigente Ley de Reforma Universitaria de 1984 en que la asignatura se desdobla en Ciencia Política y Derecho Constitucional.

\footnotetext{
${ }^{62}$ R. SALAS, R. (1821), Lecciones de Derecho Público..., ya cit., Prólogo al Tomo I, p. XI.
} 
Volviendo al Trienio Liberal, es de sobra conocida la suerte de su obra, nada desdeñable en el plano de las ideas pese a su corta duración, pero anulada apenas se inicia la conocida como Década Ominosa en 1823. Aunque no se cerraban las puertas a las ideas cada vez que los vaivenes políticos comportaron un retroceso. Es de general conocimiento, y lo recordaba Rubio Llorente ${ }^{63}$, la significación que en el plano de las ideas tuvo el fenómeno del exilio con el que se solía acompañar cada retroceso político y la consiguiente proscripción de los conocimientos liberales. Es justamente por esa vía del exilio como «no se rompe todo contacto entre los españoles de la época y las ideas que por entonces tienen curso en Europa».

\section{Evolución de la cuestión en el reinado de Isabel II}

Con el tímido aperturismo político que se inicia a la muerte de Fernando VII, se retoma el estudio de las nuevas formas políticas inicialmente fuera de la Universidad, en las célebres lecciones que dictan en el Ateneo Donoso Cortes ${ }^{64}$, Alcalá Galiano ${ }^{65}$ y Pacheco ${ }^{66}$ de cuyo estudio se ocupó Garrorena ${ }^{67}$ en forma magistral. En el período se mantiene el espíritu gaditano sobre la función política transformadora de la instrucción. Jaumeandreu es un claro ejemplo: en su Catecismo razonado sobre la Constitución de 1837 retoma los planteamientos de Salas defendiendo la necesidad imperiosa de que se erijan... Cátedras en donde se explique esta Constitución política de la Monarquía española, no solo en las Universidades, si también en todo cuerpo enseñante, pues no debe circunscribirse esta ciencia a los jurisconsultos, sino que deben penetrarla en lo posible todas las clases de la sociedad. La instrucción en esta materia debe ser general, y en nada debe el gobierno desplegar más su celo, que en procurar que se propaguen las luces... ${ }^{68}$.

${ }^{63}$ RUBIO LLORENTE, F. en «Prólogo» a STEIN, E. (1973) Derecho Político (trad. Por F. Sainz Moreno) Madrid, Eds. Aguilar, p. XII.

${ }^{64}$ Lecciones de Derecho político en Obras de DONOSO..., ya cit.

${ }^{65}$ AlCAla GAlianO, A. (1843) Lecciones de Derecho Político Constitucional, Madrid, Imprenta de D. I. Boix. A su contribución no empece el conservadurismo de sus teorías, puesto de manifiesto en la aversión que muestra a las nuevas doctrinas sobre los derechos. Así, se lee en p. 93 «...Al lado de la seguridad personal está la seguridad pública, y si bien de la segunda suele ser la primera una parte y no corta, ocasiones hay en que a la segunda se opone el que gocen algunos de los súbditos de aquella otra con latitud suma...».

${ }^{66}$ Cuyas principales obras, se han ido citando en este texto.

${ }^{67}$ GARRORENA MORALES, A. (1974) El Ateneo de Madrid y la Teoría de la Monarquía Liberal, 1836-1847. Madrid, I.E.P..

68 JAUMEANDREU, E., Catecismo razonado ó explicación de los artículos de la Constitución..., ya cit., p. II. 
A partir de 1857 se acentúa el carácter jurídico de la disciplina destacando las obras de Colmeiro ${ }^{69}$ y de Ignacio Maria Ferrán ${ }^{70}$ que, aun sin que puedan ser considerados precedentes del krausismo, ofrecen una comprensión más plural de la disciplina que los autores precedentes.

\section{La consolidación del Derecho Politico Constitucional en la Restauración}

Ahora bien, es en el período de la Restauración cuando el estudio de la disciplina ya adquiere una solidez en las categorías y los métodos que permite hablar, incluso de diversidad de Escuelas en las que se deja sentir el influjo de las doctrinas extranjeras que las informan y enriquecen. En esta consolidación la doctrina es constante en subrayar el papel de Santamaría, Posada y Soler, todos ellos de inspiración krausista. De hecho, la influencia krausista ha de subrayarse de modo especial; en primer lugar, por su significación política y sus concepciones cercanas a la monarquía parlamentaria; en segundo lugar, porque permite explicar en parte la difusión de los contenidos de la asignatura en la misma medida en que participó también de su construcción. Hombres de ciencia, pensamiento y cultura, los krausoinstitucionistas fueron los principales difusores en España de los logros de las diversas ciencias sociales y humanas - Sociología, Antropología, Historia, Derecho, Psicología Experimental,...- y a quienes se deben los esfuerzos por difundir los valores y principios de la ciencia moderna ${ }^{71}$.

Constituyeron una primera generación de intelectuales, abiertamente comprometidos con la democracia que aportaron a la renovación del pensamiento republicano textos tan representativos como El Selfgovernment y la monarquía doctrinaria, (1876), El sistema parlamentario en la práctica (1885), ambos de Gumersindo de Azcárate, y Estudios sobre el Régimen Parlamentario en España (1890), de Adolfo Posada. Su interés no está en que constituyan una avanzada en el pensamiento político europeo de su momento, sino en la acomodación del ideal republicano a los principios de una democracia parlamen-

${ }^{69}$ COLMEIRO, M. (1870) Elementos de Derecho apolitico y Administrativo de España, Madrid,. En 1881 se publica la sexta edición, Madrid, Librería de los Sucesores de Escribano.

${ }^{70}$ Extracto metódico de un curso completo de Derecho Politico y Administrativo. Barcelona, 1870. Debe citarse así mismo a CUESTA (Elementos de Derecho Politico, Salamanca, Librería de Manuel Hernández, 1895, y a ROVIRA Y RABASSA: Tratado de Derecho politico, Madrid, Barcelona, 1882.

${ }^{71}$ GONZÁLEZ ALCANTUD, J. A. y ROBLES EGEA, A. (eds. 2000), Intelectuales y ciencias sociales en la España de fin de siglo, Barcelona, Anthropos. NUÑEZ, D. (1986) ha estudiado en detalle los planteamientos teóricos y los logros científicos del krausoinstitucionismo. El krausoinstitucionismo, Madrid, Tecnos. 
taria auténtica, bajo el aliento de un organicismo de base krausista ${ }^{72}$. Ello sin perjuicio de las limitaciones a que se refiere Clavero ${ }^{73}$ al afirmar que «no existen verdaderas figuras que se consagren a la construcción de un Derecho Constitucional» y que «el propio régimen de la Constitución de 1876 apenas se beneficia de tal cultura»; en todo caso, como este mismo autor reconoce, las condiciones mas favorables que vive la libertad de expresión permiten un debate público sobre cuestiones políticas y constitucionales.

Así, con la denominación de Derecho Político se va elaborando doctrinalmente nuestra disciplina en forma ordenada y uniforme con el estudio de la estructura y funcionamiento del Estado. Al liberalismo de inspiración inglesa de Santamaría de Paredes ${ }^{74}$ se opuso el conservadurismo de Gil y Robles ${ }^{75}$ bajo la influencia de F.J. Sthal ${ }^{76}$. Pero la etapa más importante en la configuración del la disciplina, que coincide con su independización del Derecho Administrativo, está presidida por la obra de D. Adolfo Posada a quien se debe la estructuración del Derecho Político «como una disciplina enciclopédica dentro de la cual, y como una de sus partes, queda incluido el Derecho Constitucional». Basta consultar la obra de Posada para advertir la amplitud de su dedicación y la multitud de estudios que realiza bajo la rúbrica del Derecho Político y/o Constitucional: «La distinción entre Derecho Político y Derecho Constitucional, en que el Sr. Orlando (Archivio di Diritto Pubblico, mayo-junio, 1893) se fijó especialmente, paréceme clara y exacta. No he rectificado en este punto, como en muchos otros, mis opiniones. Fundamentalmente, la distinción obedece al valor histórico que tiene la palabra constitucional. En rigor, aplícase el término al Derecho Político de los Estados... constitucionales, por antonomasia, esto es, de los Estados Modernos... La Teoría del Estado es en la enseñanza de las ciencias políticas de una importancia absoluta.... (cuando se pide un estudio del Derecho Político sin determinar cómo se quiere éste (si filosófico, histórico, etc.) ha de comprenderse en él la investigación de sus problemas capitales)... La importancia del Derecho Constitucional es de otro orden. Ante la imposibilidad de una investigación

72 Una buena síntesis de estos planteamientos en SUÁREZ CORTINA, SUÁREZ CORTINA, M. (1998) «Krausoinstitucionismo, democracia y Republicanismo de cátedra en la España de fin de siglo", en Los 98 ibéricos y el mar, Madrid, tomo III, El Estado y la Política, pp. 461-486.

73 CLAVERO, B. (1984), Evolución histórica..., ya cit., pp. 198 y ss.

74 SANTAMARÍA DE PAREDES, V. (1880-81) Curso de Derecho Político, Imprenta de Ferrer y Orgá. Valencia.

75 Tratado de Derecho Politico según los principios de la filosofía y del Derecho Cristiano. Salamanca, 1889-1902.

76 «Brazo de la reacción en pro del derecho de los Príncipes», según ELÍAS DE TEJADA que, como recuerda RUBIO LLORENTE (op. cit., p. XIII) tampoco es nada sospechoso de progresismo. 
total y de una exposición enciclopédica del Derecho Político, ¿qué parte de ésta, en su aspecto histórico, puede interesar de un modo más general a las gentes todas, y sobre todo, a las gentes universitarias y a las políticas? ... el Derecho Político contemporáneo, es decir, el constitucional...».

Junto a las obras de Posada citadas, y a título de ejemplo, cabe recordar: la Guía para el estudio y aplicación del Derecho Constitucional de Europa y América7; las Instituciones Políticas de los Pueblos Hispano-americanos ${ }^{78}$; el Derecho Politico Comparado. Capitulos de Introducción ${ }^{79}$. Ahora bien, la progresiva ampliación de contenidos no acaba ahí y está sin duda propiciada por las influencias exteriores a partir del desarrollo y difusión de las teorías sociológicas y, especialmente, del desarrollo de la ciencia política en el mundo anglosajón. Basta recordar la obra de traducción que se lleva a cabo en esos años. Así, los Tratados de Política ${ }^{80}$ de Gumersindo Azcárate, de 1883, que, no en vano, subtitula Resúmenes y Juicios criticos o la traducción con Estudio preliminar que realiza Posada sobre Las transformaciones del Derecho Público, de León Duguit ${ }^{81}$.

También llama la atención en las consultas bibliográficas cómo nuestros estudiosos van introduciendo un nuevo enfoque social en el Derecho Constitucional completándose así las diversas facetas con que se conoce en la actualidad. Así, por ejemplo, Adolfo Posada publica en el segundo tomo de su Derecho Administrativo dedicándolo a La Administración política y la Administración social; en la parte que dedica a ésta, desde luego mucho más reducida que la otra, cabe hallar rudimentos, pero de gran interés que nada han de envidiar a las obras extranjeras que usualmente manejamos como primeros referentes del Estado social. Lo mismo cabe decir de Santamaría de Paredes del que bastará citar ahora su Discurso sobre El movimiento obrero contemporáneo ${ }^{82}$ en el que, sobre dar muestra de sus conocimientos en cuantas ideas circulaban por Europa, refleja su propia

77 Madrid, Librería de Victoriano Suárez, 1894. Prólogo (pp. X y XI).

78 Madrid, Hijos de Reus, Editores, 1900.

79 Madrid, Librería General de Victoriano Suárez, 1906. Estos capítulos tienen un extraordinario interés para la reflexión sobre la enseñanza del Derecho Constitucional por lo que vale la pena reproducir siquiera sus grandes epígrafes: I, La enseñanza en las Ciencias Políticas; II, La enseñanza del Derecho Político en la práctica; III, Transformaciones recientes del Derecho Político; IV, El método comparativo.

${ }^{80}$ DE AZCÁRATE, G. (1883) Tratados de Política. Resúmenes y Juicios críticos. Madrid, Imp. de Enrique de la Riva.

${ }^{81}$ DUGUIT, L. (1915), Las transformaciones del Derecho Público, Madrid, Fco. Beltrán, Librería española y Extranjera.

${ }^{82}$ Leído ante la Real Academia de Ciencias Morales y Políticas en su recepción el día 15 de mayo de 1893. Madrid, Establecimiento tipográfico de Ricardo Fe, 1893. 
concepción del Estado social defendida, por lo demás, en la Conferencia internacional celebrada en Berlín, en 1890, a instancias del Emperador alemán, a la que Santamaría de Paredes acudió como delegado del Gobierno español.

\section{MADURACIÓN DE LAS IDEAS PRECEDENTES EN TORNO A LOS DERECHOS DE PARTICIPACIÓN Y/O LIBERTADES PÚBLICAS}

Por último, he de insistir en el papel del estudio y desarrollo de las libertades públicas y su significación para el nuevo Estado Constitucional que va naciendo. Justamente Adolfo Posada ${ }^{83}$ les dedica una directa y detenida extensión que no puede ser aquí ignorada. Antes de entrar en el desarrollo de las mismas analiza Posada, en el Libro IV de su Tratado, los derechos de la personalidad y su relación con el Derecho Constitucional, discrepando de sus contemporáneos que hacen girar tales derechos en torno a la idea de libertad ${ }^{84}$. En mi opinión tal idea sigue vigente como también su advertencia sobre la imposibilidad de asimilar todas las categorías de derechos. Pues el error a su juicio se deriva del empeño en conceptuar los derechos de la personalidad «en relación con el Estado» cuando se trata de las más mínimas necesidades, condiciones esenciales de «la vida del ser de razón en sí mismo y en las manifestaciones diversas de su actividad...». También cree que es inexacto atribuirlos al individuo pues corresponden no a él sino a toda persona y, por ello, también las jurídicas entre las que se incluye al Estado. El tercer error que cree se suele cometer es el de considerar esta teoría de los derechos de la personalidad como teoría y organización de la libertad cuando, en realidad, se trata de una doctrina general jurídica.... Para, después, preguntarse: ¿qué relación guardan, pues, estos derechos de la personalidad con el Derecho político? Han de estudiarse básicamente en la Teoría del Estado. Pero algo hay que decir también en Derecho Constitucional ${ }^{85}$.

83 POSADA, A. (1894). Tratado de Derecho Político. Madrid, Librería de Victoriano Suárez.

${ }^{84}$ «A mi modo de ver, aunque inexacta e inadmisible la consideración de los derechos de la personalidad, primero como teoría de las relaciones entre el individuo y el Estado, segundo como teoría de la libertad, y mucho menos, tercero, como una teoría de la libertad individual, tal consideración explícase por los mismos motivos que determinan en la práctica las confusiones reinantes, a saber, las formas extraordinarias y los caminos tortuosos por los que se ha introducido en el derecho constitucional la idea filosófica que implica la consagración solemne política, esto es, hecha a nombre del Estado, de los derechos de la personalidad como derechos del hombre y del ciudadano" (POSADA, A. (1894). Tratado... ya cit., p. 399).

${ }^{85}$ El planteamiento resulta extraordinariamente llamativo y ya lo vimos defendido también en el período cristino según las notas supra incluidas de Nieto. Pero hoy sigue teniendo vigencia pues, 
Desde esta perspectiva, entiende Posada que no cabe olvidar lo siguiente: Que el Estado es persona y tiene sus propios derechos frente a otros Estados y frente a los mismos individuos "que suelen desconocerla [su autonomía e independencia] más a menudo de lo que pudiera creerse». Que el Estado, al garantizar el Derecho y su eficacia, condiciona inevitablemente los derechos de la personalidad pero esta relación se establece "por razón de su fin mismo: que el derecho impere; y así se mide el grado de civilización de una sociedad política, por el de las garantías con que espontáneamente se gozan los beneficios que los derechos personales suponen ${ }^{86}$. Solo que los malos entendidos también en este campo tienen su explicación: es justamente el nacimiento de los derechos, incluso los mas personales, en enfrentamiento con el poder del que por la fuerza se han ido obteniendo garantías, lo que justifica que incluso estos derechos se expliquen en relación con aquel. Sentadas estas premisas, en el libro $\mathrm{V}$ se ocupa de la organización del Estado constitucional dedicando el primero de sus capítulos ("Criterio general y base de la organización del Estado») a la sociedad (aunque en términos muy laxos) y a la configuración de la opinión pública. A ésta dedica el capítulo II para, en el III, detallar la formación y organización de la misma explayándose, por tanto, en este fenómeno que considera básico en la organización del nuevo Estado. Tras estos iniciales fundamentos se introduce en la exposición de las que podríamos considerar tres libertades públicas clásicas o típicas: Reuniones públicas, asociaciones y prensa política así como los partidos políticos para, sólo después del conocimiento de las mismas, estudiar el sufragio. El Tratado entra en estudio de los tres poderes clásicos tras establecer como bases indiscutibles del nuevo Estado constitucional las ya referidas.

Sobre las tres clásicas libertades empieza negando que constituyan características, exclusivamente, del Estado Constitucional Contemporáneo. En todos los tiempos las ha habido aún en forma rudimentaria porque tales manifestaciones son condición de la sociedad en sí mismas. Pero no es menos cierto que «revisten en el organismo político moderno un carácter especial dependiente de la naturaleza esencialmente representativa del Estado...» de suerte que, considerados en la función especifica que en el Estado desempeñan, «tienen algo que es de ahora, del Estado constitucional, determinado o producido por la importancia creciente de su acción política» ${ }^{87}$. No en vano estamos ante elementos

tal como me refería en la primera nota a la reciente Jornada sobre el Derecho Constitucional hoy ante las nuevas tecnologías y a cuantas reflexiones se suscitaron en ella, aun hoy nuestro jóvenes profesores se siguen preguntando por los contenidos y han de hacerlo más que nunca ante los nuevos Planes de estudio en que se impone la coordinación entre las diversas disciplinas de cada curso.

${ }^{86}$ POSADA, A. , Tratado..., pp. 309-403.

${ }^{87}$ Ibidem, pp.. 470-1. 
esenciales de la forma de Estado: «la vida de éste, en las sociedades modernas, implica para la buena dirección de sus energías y actividades, reuniones políticas, asociaciones políticas y prensa política, con igual necesidad y con análoga fuerza que los instrumentos de gobierno ${ }^{88}$ ».

Aunque lógicamente ello exige un mínimo de movilización y educación: Las gentes que se interesan de algún modo en la marcha del Estado, que tienen conciencia de su condición de ciudadanos, aunque sea de las que pueden votar, encuentran en las reuniones un medio indispensable para hacer sentir su influjo y para formar su opinión; en las asociaciones, medio ambiente donde definir sus aspiraciones; en la prensa, alimento diario a su curiosidad justificada... ${ }^{89}$. Todo lo cual resulta coherente con el régimen de publicidad que debe regir el Estado: Además, teniendo en cuenta la amplísima base representativa que hemos asignado al Estado moderno en su función de organizarse, las reuniones, asociaciones y prensa, comprendiendo una gran masa de ciudadanos, pero nunca la totalidad de éstos, entrañan un paso de la acción general, vulgar, de todos los miembros del Estado, hacia el hacer reflexivo y definido y menos extenso, en definitiva artístico, que supone el Gobierno...» [Ellas] determinan, en quienes de alguna manera toman parte en aquéllas... una acción política personal que exige cierta intencionalidad y cierta intervención reflexiva en la formación y vida del Estado» ${ }^{90}$.

Como tampoco se ignora en la época el carácter institucional de estos derechos: «...como consecuencia necesaria del carácter jurídico del Estado y del reconocimiento expresamente declarado de su índole representativa, se consagra de un modo mas o menos explícito en las leyes la existencia de las reuniones... no solo por los individuos, que es en el respeto en que suelen considerarse sobre todo, sino por el Estado... De ahí el significado que es preciso dar a las declaraciones constitucionales, o meramente legales, que en los Estados se hacen relativas a los derechos del ciudadano (no de toda persona), para hacer uso de los medios a que nos referimos ${ }^{91}$. Lo que no impide la diversidad de soluciones que el Derecho comparado ofrece para su regulación y, por lo que se refiere a España, su tratamiento legal receloso y desconfiado: «Si se toman como derechos individuales, las legislaciones y las costumbres implican soluciones de amplia libertad contrayéndose el poder a reprimir su empleo ilegítimo «o sea los delitos que por

88 Ibidem.

89 Ibidem.

90 Ibidem, p. 472.

91 Ibidem, p. 473. La precisión del sujeto (el ciudadano) no debe pasar desapercibida pues permite observar la contraposición con el que se considera sujeto universal de los derechos de la personalidad sobre el que ya supra se dejó dicho que son todas las personas. 
tales medios se pueden cometer»; siendo éste el criterio inglés y norteamericano, existe sin embargo otra interpretación en nuestro entorno continental, ... de desconfianza, que en un grado variable procura revestir al poder constituido de facultades que se dirigen a prevenir por mil maneras las perturbaciones públicas que del ejercicio indebido (abuso) de los derechos de reunión, asociación y prensa, pueda resultar»...Realmente, cuando se organiza jurídicamente el empleo de los medios que las reuniones, asociaciones prensa suponen, se parte de errores muy lamentables. El primero y capital es el de suponer que... es un litigio entre el Gobierno y el individuo... cuando... de lo que se trata es de declarar, de reconocer y de condicionar el ejercicio de la actividad personal en función de hacer política y olvidando que la acción del poder... ha de ser meramente represiva. Además, no suele tenerse en cuenta la necesidad de distinguir entre reuniones, asociaciones y prensa no políticas y las políticas, no para limitar éstas más que las otras, sino para considerarlas como funciones del Estado.... Por fin, suele no tenerse presente... que la organización del Estado, para producir un gobierno propio, es decir, un Gobierno que surja directa y reflexivamente de la sociedad, por el natural y espontáneo movimiento de todas sus fuerzas, exige que no se oponga obstáculo alguno a la formación normal y constante de la opinión, y tampoco a las manifestaciones pacíficas de ésta ${ }^{92}$.

Con tantas aportaciones del siglo XIX se inicia el XX que en la etapa anterior a la guerra civil se caracteriza, según Ollero $^{93}$, por la apertura a todas corrientes extranjeras estimulada por la concesión de numerosas pensiones y becas de estudio y por una acentuada labor traductoria» ${ }^{94}$. De hecho cabe apreciar las

92 Ibidem, pp. 474-475.

93 OLLERO, C. (1955) «El Derecho Político como Ciencia Política», en Estudios de Ciencia Política. Madrid, Ed. Nal., p. 148.

94 Basta la consulta de los autores de la época que estamos citando para comprobar su ilustración y el uso de referentes extranjeros. En este sentido, la consulta de los índices de La España Moderna referidos a los años 1890-1910 nos ofrece tal volumen de notas bibliográficas y recensiones realizadas por don ADOLFO POSADA que nos ha parecido merecedor de un anexo a esta reflexión en el que se puede comprobar el conocimiento que nuestros tratadistas tenían de la doctrina extranjera. Por su parte SANTAMARÍA DE PAREDES, por seguir citando sólo algún ejemplo significativo, publica en 1901 el Discurso leido en la Universidad Central en la solemne inauguración del curso académico de 1901 a 1902 (Madrid, Imprenta colonial), sobre El concepto de sociedad, en cuyas notas a pié de página podemos hallar referencias actualizadas sobre el tema tanto de la bibliografía alemana y francesa como también, aunque en menor medida, de la anglosajona. Un último ejemplo cabe subrayar: el libro de AZCÁRATE, G., Tratados de Política, Resúmenes y Juicios Críticos (Madrid. Imp. de Enrique de la Riva, 1883) no es sino, como el título fielmente indica, un conjunto de resúmenes de libros y autores extranjeros como Minghetti, Sansonetti, Lorimer, Passy, etc. 
siguientes tendencias: la supervivencia del krausismo de Fernando de los Ríos, una destacada influencia inglesa apreciable en Teodoro González y Tomás Elorrieta así como el moderno catolicismo político y social que trasciende en la obra de Ruiz del Castillo95. Por último, en la obra de Pérez Serrano cabe comprobar el grado de sistematización y rigor que había alcanzado la disciplina observando ya la plena diferenciación de sus partes como es el caso de la Teoría General del Estado y el Derecho Constitucional propiamente dicho.

Pero todo ello ya pertenece a otro siglo que comienza, como acabamos de ver con los frutos que el siglo XIX ha ido madurando. Si comenzamos con referencia a la incidencia de la realidad política en la obra doctrinal así hemos de terminar también puesto que en nuestro siglo XX la disciplina sufre tan radical y prolongada suspensión que, en cierto modo, sólo después de la Constitución vigente de 1978 cabe hablar de reconstrucción del Derecho Constitucional aunque el avanzado estado de la disciplina en la Europa occidental inclinó a la doctrina, como parecía lógico, a beber de las fuentes comparadas. Era lógico desde el punto de vista estrictamente jurídico y desde la experiencia del control concentrado de constitucionalidad que había ido depurando (fundamentalmente en Alemania aunque también en Italia y, con las lógicas distancias del Conseil Costitutionnel, incluso en Francia) los ordenamientos democráticos que nos habían de servir de modelo, que la doctrina se centrara en todo ello. Sin embargo, tal vez no hubiera estado de más retomar algunas de las preocupaciones de nuestra doctrina de final del XIX y principios del XX que aquí hemos recordado, especialmente las referidas a la comprensión de los distintos grupos de derechos y en particular a la especial significación de las libertades públicas y al papel institucional que las mismas jugaron en el asentamiento de la democracia ( $y$, habrá que añadir, en la conservación y fortalecimiento, aun hoy, de la misma).

Siendo así todo ello, al menos desde mi perspectiva, la presencia de las nuevas tecnologías en las aulas y los extraordinarios medios que nos ofrecen en la función docente no debe hacernos perder de vista el riesgo de dispersión que de tan completas y complejas fuentes de conocimiento puede derivar. Salvo, claro es, que se le proporcione a quienes han de trabajar con tales medios un marco claro tanto de métodos como de contenidos.

95 RUIZ DEL CASTILLO y CATALÁN DE OCÓN, C. (1939), Manual de Derecho Politico. Madrid, Reus. 
Title

THE GERM OF THE CONSTITUTIONAL LAW LIKE JURIDICAL DISCIPLINE IN THE NINETEENTH-CENTURY SPANISH CONSTITUTIONALISM

\title{
Sumary
}

I. IDEAS AND CONSTITUTIONAL FOUNDATIONS; DETERMINING OF THE POLITICAL REALITY IN THE SPAIN OF THE XIXTH. 1. The first Spanish constitutionalism. 2. Intermediate period of apparent stagnation. 3. The doctrinaire liberalism of the Spanish Constitution of 1845 and the failure of the Progressive Period of two years (1854-56). 4. The last Third of de XIX century. Special significance of the period of the Restoration. 4.1. Nex to the juridical technics, they light those of democratic nature. 4.2. Social dimension of the constitutional State. II. THE SPANISH CONSTITUCIONAL LAW IN THE FIRST MANIFESTATIONS OF THE MANUALÍSTICA. 1. Catechisms to announce the Constitution. 2. His evolution in the reign of Isabel II. 3. The consolidation of the Constitutional Constitutional law in the Restoration. III. RIPENESS OF THE PREVIOUS IDEAS CONCERNING THE RIGHTS OF PARTICIPATION AND / OR PUBLIC FREEDOMS.

\section{Resumen}

Se trata de demostrar en este trabajo que el Derecho Constitucional como disciplina objeto de estudio en nuestras Facultades de Derecho cuajó tardíamente respecto de la aparición de las primeras Constituciones liberales. Sin embargo, todas las etapas constitucionales fueron dejando sus propias contribuciones y, aunque muy lentamente, llegaron a cuajar en una serie de materias sistematizadas, propias de la disciplina jurídica que se estudia, al llegar el fin del siglo XIX y el inicio del XX. Sin embargo, sus contenidos básicos, entonces formulados, no deben ignorarse siquiera hoy tras tantos cambios sociales y tecnológicos.

\begin{abstract}
Abstrac
One tries to demonstrate here that the Constitutional law, like discipline of study in the spaniards Faculties of Law, It curdled late respect of the appearance of the first Constitutions. Nevertheless, all the constitutional stages were leaving his own contributions and, very slowly, they managed to become set in a series of systematized, own matters of this juridical discipline, when came the end of the 19th century and
\end{abstract}


the beginning of the XXth. Nevertheless, his basic, at the time, formulated contents, they must not be ignored, even today, after so many social and technological changes.

\section{Palabras clave}

Constitucionalismo, Principios fundamentales del Derecho Público y del Derecho Constitucional. Siglo XIX.

\section{Key words}

Constitutionalism, Fundamental principles of the Public law and of the Constitutional law. Nineteenth-century. 